\title{
Denboraren gezia
}

David Brizuela

Fisika Teorikoa eta Zientziaren Historia Saila, UPV/EHU

david.brizuela@ehu.eus

DOI: $10.1387 /$ ekaia.11967

Onartua: 2015-02-19

Laburpena: Denboraren gezia denboran norantza berezi bat finkatzen duen edozein efektu edo prozesu bezala defini daiteke. Artikulu honetan denboraren geziaren kontzeptua aztertuko da fisikaren arlo desberdinen ikuspuntutik. Funtsean fisikaren legeak bi multzotan banatzen dira. Alde batetik, oinarrizko partikulek jarraitzen dituzten legeak denboran simetrikoak dira. Beste aldetik, partikulen sistema makroskopikoei aplikatzen zaizkienek, termodinamikaren bigarren printzipioak bereziki, denboran asimetria bat finkatzen dute. Nola izan daiteke denboran asimetria bat egotea azpitik dauden legeak itzulgarriak izanik? Itzule-zintasunaren paradoxa hau aztertuko da eta literaturan proposatu diren erantzun posibleak eztabaidatu.

Hitz-gakoak: Denboraren gezia, termodinamika, entropia, itzulezintasunaren paradoxa.

Abstract: The arrow of time can be defined as any effect or process that fixes a special direction on time. In this article the concept of the arrow of time will be analyzed from the perspective of the different areas of physics. Essentially the laws of physics can be classified into two different sets. On the one hand, laws obeyed by elementary particles are time-symmetric. On the other hand, those that are applied to macroscopic systems of particles, especially the second principle of thermodynamics, fix an asymmetry in time. How is it possible that a time asymmetry is present if the underlying laws are completely reversible? This irreversibility paradox will be analyzed and the possible answers presented in the literature will be discussed.

Keywords: Arrow of time, thermodynamics, entropy, irreversibility paradox.

\section{SARRERA. ZER DA DENBORA?}

Galdera hutsala dirudi honek, hain ohituta baikaude denbora egunero neurtzera. Baina definizio zehatz bat ematen saiatuz gero arazo larrietan sartuko ginateke. Aipa daiteke San Agustin Hiponakoak 400. urte aldera idatzitakoa [1]: «Zer da, bada, denbora? Inork galdetzen ez badit, badakit zer den, baina galdetzen didanari azaldu nahi badiot, orduan, ez dakit.» 
Antzinako zibilizazio gehienen aburuz, denbora ziklikoa da. Mito asko aurki daitezke historian zehar munduaren amaiera iragartzen dutenak, eta amaieraren ondoren bersortuko dela aurresaten dutenak, ziklo berri bati hasiera emateko. Ziklo hauek infinituraino errepikatuko lirateke behin eta berriro. Greziar filosofo askok ideia hau muturreraino eraman zuten betiereko itzultzea proposatuz. Ikuspegi honen arabera, gizaki guztiak behin eta berriro jaio eta bizitza berbera bizitzera kondenaturik egongo ginateke. Ikusiko dugun moduan, XIX. mendean Poincare-k ideia hau matematikoki berpiztu zuen. Beste batzuek soilik uste zuten historiak eskema zikliko jakin batzuk jarraitzen zituela, baina ez zirela gertaera berberak errepikatuko; horregatik jotzen zuten denbora zirkulartzat.

Denboraren zirkulartasunaren ideiak naturaren zikloetan oinarriturik egoteagatik izan zuen onespen handia. Hots, planeta eta izarren mugimenduak, mareak, urtaroak... denak ziklikoak dira; beraz, zergatik historia ez da ziklikoa izango?

Gaur egunean, ostera, denbora iraganetik etorkizunera doan lerro zuzen baten moduan irudikatzen dugu. Pentsatzeko modu hau erlijio kristautik datorkigu. Lehen idazle kristauek garrantzi handia eman zieten inoiz errepikatuko ez ziren gertaera batzuei. Haientzat jainkoaren semea behin besterik ez zen hil gurutzean eta behin besterik ez zen altxatu hildakoen artetik. Jainkoak momentu jakin batean sortu zuen mundua eta apokalipsiak munduaren behin betiko amaiera ekarriko du.

Baina hori ez da izan denboraren kontzeptuak historian zehar izan zuen aldaketa bakarra. Gaur egunean denbora orduak eta minutuak bezalako unitate abstraktuetan banatzen dugu, baina Erdi Aroaren amaiera arte denbora naturaren zikloekin soilik neurtzen zen; edo gehienez, eguna 12 ordutan eta gaua beste hainbatetan zatitzen zen, ordu horiek iraupen desberdina zutelarik, noski. Baina lehenengo erlojuak asmatu zirenean, denbora kontzeptu abstraktu eta neurgarri bilakatzen hasi zen; hau da, haren existentziak jada ez zuen naturaren zikloekiko menpekotasunik. Horrela, Galileok denbora magnitude fisiko moduan ulertu ahal izan zuen, eta fisikari gaur egun oraindik jarraitzen duen bidea ireki zion. Nahiz eta denborak teoria fisiko guztietan parte hartzen duen, esan dezakegu magnitude ezezagunen edo gutxien ulertzen direnen artean dagoela.

Artikulu honetan zehar, denboraren propietate bat aztertzen saiatuko gara fisikaren ikuspuntutik: beraren norantza.

\section{DENBORAREN GEZIAK}

Denboraren geziaren kontzeptua Eddington-ek definitu zuen denboran asimetria bat finkatzen duten elementuei aipamena egiteko [2]. Guk beti 
nabaritzen dugu denbora norantza batean doala. Hau da, guretzat iragana finko mantentzen da, etorkizuna, berriz, irekia eta oraindik existentziarik gabea den bitartean. Etorkizunaren dokumenturik ez existitzeak, hala nola fosilak, eta etorkizuna ezin gogoratzeak (Erregina Zuriak Aliziari esan zion moduan: «Oroimen txarra hori, soilik atzerantz dabilena» ${ }^{1}$ [3]) argi uzten dute egunero nabaritzen dugun denboraren asimetria hori. Horri denboraren gezi psikologikoa deitzen zaio. Hala ere, guk denbora horrela nabaritzeak ez du zertan esan nahi halakoa denik, gure zentzumenek errealitatearen hurbilketa baino ez baitigute eskaintzen.

Filosofo askok defendatu izan duten moduan, denboraren gezia guztiz subjektiboa izan daiteke; hau da, gure garunak eta zentzumenek eraturiko ilusio hutsa. Izatez, fisikaren hainbat teoriak ideia horren partaide izatera bultzatzen gaituzte, ez baitute inongo bereizkuntzarik egiten etorkizunaren eta iraganaren artean. Teoria horien artean Newton-en mekanika eta Einstein-en erlatibitatea daude.

Newton-en ekuazioek predikzio ahalmen izugarria eskaintzen digute. Baina, aurrerago ikusiko dugun moduan, ez dute eskaintzen inongo baliabiderik denboraren norantza positiboa aukeratzeko. Einstein-en erlatibitatea mekanika klasikoaren ordezkatzaile izateko jaio zen, eta denboraren kontzeptua asko aldatu zuen arren (denbora erlatiboa dela erakutsiz), mekanika klasikoaren arazo berbera dauka denboraren norantzari dagokionez, guztiz determinista baita denboran aurrera zein atzera.

Baina ekin diezaiegun denboran norantza bat aukeratzeko gai diren gertaerei; hots, denboran itzulezinak direnei, gertarea horiek norantza batean soilik gerta baitaitezke. Honako hauek dira artikulu honetan zehar aztertuko ditugun denboraren geziak:

- Kuantikoa: oinarrian, teoria kuantikoak mekanika klasikoaren arazo berberak dauzka denboraren gezi bat finkatzeko, Schrödinger-en ekuazioa guztiz simetrikoa eta determinista baita denboran, nahiz eta kasu honetan ekuazio horren emaitzak probabilitateak diren. Dena dela, teoria kuantikoak bi elementu eskaintzen dizkigu denboran asimetrikoak direnak. Lehenengoa neurketaren arazoa da: neurketa bat aurrera eramatean uhin-funtzioaren kolapsoa eragiten dugu, eta kolapsoa itzulezina da. Bigarrena oinarrizko partikula batek emango digu: $\mathrm{K}$ mesoi neutro edo kaoi delakoak. Haren desintegrazio prozesu batzuk ez baitira simetrikoak denboran.

- Erradiazioarena: fisikaren oinarrizko lege guztiak bezala, Maxwell-en elektromagnetismoko ekuazioak guztiz simetrikoak dira denboran. Haietatik abiatuz, uhin-ekuazioa ondorioztatzen da uhin

\footnotetext{
1 «It's a poor sort of memory that only works backwards.»
} 
elektromagnetikoentzat. Ekuazio horrek bi soluzio onartzen ditu: etorkizunerantz hedatzen den uhina eta iraganerantz hedatzen dena. Esperimentalki soilik etorkizunerantz doan uhina neurtzen da. Hots, izarrek zein bonbillek sorgunetik dibergitzen duten uhinak igortzen dituzte; uhinak ez dira infinituan sortzen eta ondoren izar edo bonbilletan xurgatuak izaten.

- Termodinamikoa: termodinamikaren bigarren legea denboran asimetria bat esplizituki finkatzen duen fisikaren lege bakarra da. Haren arabera, unibertsoaren entropia beti handitzen da. Beraz, denbora positiboaren norantza entropia handitzen den hura izango da. Prozesu biologikoetan duen aplikagarritasuna dela eta, badirudi gezi psikologikoa ere lege honetan oinarritzen dela.

Termodinamikaren gezia funtsezkoena da guztietatik. Nahiz eta lege fenomenologiko batean oinarriturik egon, fisikari askok termodinamikaren legeak lege dinamikoak baino garrantzitsuagotzat jo izan dituzte. Horren adierazgarri Eddington-en hitzak [2]:

«Entropiaren handipenaren legeak, nire ustez, naturaren legeen artean goreneko posizioa dauka. Norbaitek nabarmentzen badu zure unibertsoaren teoria kutunena Maxwell-en ekuazioekin bat ez datorrela, orduan okerrago Maxwell-en ekuazioentzat. Behaketekin kontraesanean badago, tira, esperimentatzaile hauek hanka sartzen dute batzuetan. Baina zure teoria termodinamikaren bigarren legearen aurka badago, ezin dizut itxaropenik eman; ez dauka apalkuntza sakonenera erortzea besterik.» ${ }^{2}$

Hiru gezi hauetaz gain, beste gezi batzuk ere definitzen dira hainbat testuingurutan, baina printzipioz ez dira aipatu ditugunak bezain oinarrizkoak. Haien artean daude honakoak:

- Eboluzioa: Darwin-en eboluzioaren teoria bigarren legearen kontraesan moduan ager dakiguke. Baina, ikusiko dugun moduan, ingurunearen entropia kontutan hartuz gero, ez dago inolako kontraesanik. Hau da, unibertsoaren entropia handitzen da, baina unibertsoak ez du zertan monotonikoki eta uniformeki desordenarantz joan behar; ordena ager daiteke lokalki, autoantolaketa deritzon prozesuaren bidez [4]. Autoantolaketak beste denboraren gezi bat eskain-

2 «The law that entropy always increases holds, I think, the supreme position among the laws of nature. If someone points out that your pet theory of the universe is in disagreement with Maxwells equations, then so much the worse for Maxwells equations. If it is found to be contradicted by observation, well, these experimentalists do bungle things sometimes. But if your theory is found to be against the second law of thermodynamics, I can give you no hope; there is nothing for it but to collapse in deepest humiliation.» 
tzen digu eta sasi-paradoxikoki bigarren legeak finkaturiko norantza berean begiratzen du.

- Unibertsoaren eboluzioa: unibertsoa hedatzen ari da; beraz, hori har dezakegu denbora positiboaren norantza moduan. Baina ez dago argi horrek horrelaxe izaten jarraituko duenik; gerta daiteke egunen batean grabitateak hedakuntza geldiaraztea eta unibertsoa kolapsatzen hastea. Orduan denborak atzerantz egingo al du? Galdera horri erantzuna emateko termodinamikara jotzen da, entropia kontzeptua grabitateari aplikatzen saiatuz. Ikusiko dugunez, oraindik ez dago argi hau zehazki nola egin daitekeen, baina interpretazio gehienen arabera denboraren gezi hau termodinamikaren geziaren baitan ulertzen da.

\section{DENBORA MEKANIKAN ETA ERLATIBITATEAN}

Newton-en ekuazioak erlazioan jartzen du $m$ masako partikula batek jasaten duen $\vec{F}$ indarra partikularen $\vec{r}$ posizioaren bigarren deribatuarekin:

$$
\vec{F}=m \frac{d^{2} \vec{r}}{d t^{2}}
$$

Demagun $\vec{r}(t)$ ekuazio diferentzial horren soluzioa dela. Beraz, $\tilde{t}=-t$ aldagaia-aldaketa eginez lortzen dugun ekuazioaren soluzioa $\vec{r}(-t)$ izango da. Hots, denboran aurrera zein atzera, Newton-en ekuazioa jarraituz higituko da partikula. Hala ere, horrek ez du esan nahi Newton-en ekuazioa denboran simetrikoa denik. Nahiz eta eskuineko gaia aldaezina izan $t \rightarrow \tilde{t}$ aldagai-aldaketarekiko, oro har ezkerrean agertzen den indarrak denbora eta $v=d \vec{r} / d t$ abiadurarekiko menpekotasuna izango du. Azter ditzagun bi kasu berezi.

Indarra denbora eta abiaduraren menpekoa ez bada (edo horien funtzio bikoitia bada, adibidez bere adierazpenean soilik $t$ eta $v$-ren berredura bikoitiak agertzen badira), indarraren eragina berbera da denboraren bi norantzetan. Kasu horietan Newton-en ekuazioa simetrikoa da denboran. Hau da izatez oinarrizko interakzioen kasua; honela grabitatea erakarlea eta bi karga positiboren arteko indarra aldaratzailea da denboraren alde batera zein bestera.

Bestalde, indarra denbora eta abiaduraren funtzio bakoitia bada (beraren adierazpenean abiaduraren edo denboraren berredura bakoitiak agertuz gero), $\tilde{t}=-t$ egitean zeinu negatibo bat agertuko da ekuazioan, eta horrela indarraren eragina aurkakoa bihurtuko da. Horren adibide garbia marruskadura-indarrarena da. Indar hau fenomenologikoa da, ez oinarrizkoa, hainbat elkarrekintza mikroskopikoren efektu makroskopikoa baita, eta ekuazioetan 
eskuz sartu ohi da abiadurarekiko proportzionala den gai baten bidez. Denbora positiboan gai hori balaztatzailea izango da (higiduraren aurkako indar bat eginez), baina denbora negatiboan, berriz, azeleratzailea izango da (higiduraren norantzan egingo du indarra). Mekanikaren legeek ez dute debekatzen pilota batek lurreko beroa xurgatu eta energia zinetiko bilakatzea.

Beraz, edozein mugimendu pelikula batean grabatu eta atzekoz aurrera ikusiz gero, ikusiko ditugun mugimendu horiek guztiek mekanikaren legeak beteko lituzkete, nahiz eta guztiz arraroak iruditu. Gure senak denboraren gezi psikologikoa errespetatzera deitzen gaitu, baina halabeharrez horrela izan behar izateko arrazoi objektiboak aurkitu arte, ezin dugu ziurtatu guk nabaritzen dugun denboraren norantza ez dela ilusio hutsa.

Lege hauek, itzulgarriak diren heinean, ezin dute denboraren norantza zein izango den erabaki. Horregatik esan daiteke Newton-en mekanikak gure unibertsoa atenporal bihurtzen duela, denboraren fluxua guztiz ezereztatzen baitu. Horren adibide garbia Laplace-ren supergizona (edo demonioa) deiturikoa da $[5,6]$, zeinek une batean unibertsoko partikula guztien posizio eta momentua ezaguturik, Newton-en ekuazioa askatuko lukeen eta horrela iragan zein etorkizun osoak ezagutuko lituzkeen. Horrek guztiz ezerezten ditu eboluzio eta aldaketaren kontzeptuak, izaki horrentzat aldi berean existizen baitira bai iragana bai eta etorkizuna, denboraren geziari garrantzia osoa kenduz.

Aipa dezagun, bide batez, Newton-en mekanikan oinarrituz Poincare-k proposaturiko errekurrentziaren teorema. Haren arabera, espazioan mugaturik (partikulak infinitura joan ezin daitezkeelarik) dagoen edozein sistema mekaniko arbitrarioki hurbil kokatuko da bere hasierako egoeratik denbora finituan. Hori irudikatzeko, demagun marruskadurarik gabeko billar mahai batean hainbat bola ditugula mugimenduan; denbora nahikoa utziz gero, denak hasierako posizio eta abiaduretara bueltatuko dira. Edonola dela, naturako edozein partikula-sistemaren errekurrentzia-denbora $10^{24}$ urteren magnitude ordenakoa da, hots, gure unibertsoaren adina $\left(10^{10}\right.$ urte) baino askoz handiagoa. Gainera, Poincare-ren errekurrentzia oso aplikagarritasun murritzekoa da, soilik sistema finitu eta ez grabitatorioei aplikatzen baitzaie. Hori horrela da, alde batetik, sistema infinituen errekurrentzia-denbora infinitua delako eta, bestetik, grabitatearen eragina materia guztia elkartzea, inoiz ez aldentzea, delako. Hala ere, teorema honek denbora ziklikoaren ikuspegia berpizten du. Ikuspegi honek, nahiz eta atxikituriko denboraren gezi bat izan dezakeen, Laplace-ren supergizonarekin gertatzen den bezala, eboluzioaren kontzeptua baliogabetzen du, eta ondorioz denboraren gezia garrantzi gabekoa bihurtzen da.

Newton-ek denbora magnitude absolutu gisa, unibertso osoan era berean igarotzen dena bezala, definitu zuen [7]. Baina beraren teorian denbora parametro matematiko modura baino ez da agertzen. Denborak mu- 
gimendua azaltzen edo parametrizatzen du, eta ez alderantziz, horrela denborak magnitude lehen bat izaten jarraitzen du, definiziorik gabekoa.

Mekanikaren legeek gehienez egin dezaketena gertaerak ordenatzea da, adibidez lerro zuzen baten gainean irudikatuz, baina ezin dute esan lerroaren zein norantzari jarraitu behar diogun. Bestalde, orain azalduko dugun moduan, erlatibitateak kausalitatea erabiltzen du gertaeren ordena tenporala ezartzeko.

Einstein-en erlatibitateak aldaketa sakonak eragin zituen denboraren kontzeptuan. Argiaren abiadura finitua eta behatzaile guztientzat (nahiz eta elkarrekiko higidura erlatiboan egon) bera dela dioen hipotesitik abiatuz, aldiberekotasuna eta denboraren fluxua erlatiboa dela ondorioztatzen du haren teoriak. Teoria horretan espazio tarteak ere erlatiboak dira. Baina defini daiteke behatzaile guztientzat berbera den objektu matematiko bat, $\sigma$, bi gertaeraren arteko espazio-denborazko distantzia hain zuzen:

$$
\sigma^{2}=s^{2}-c^{2} t^{2} .
$$

Definizio horretan, $s$ bi gertaeraren arteko distantzia da, $t$ denbora tartea eta $c$ argiaren abiadura.

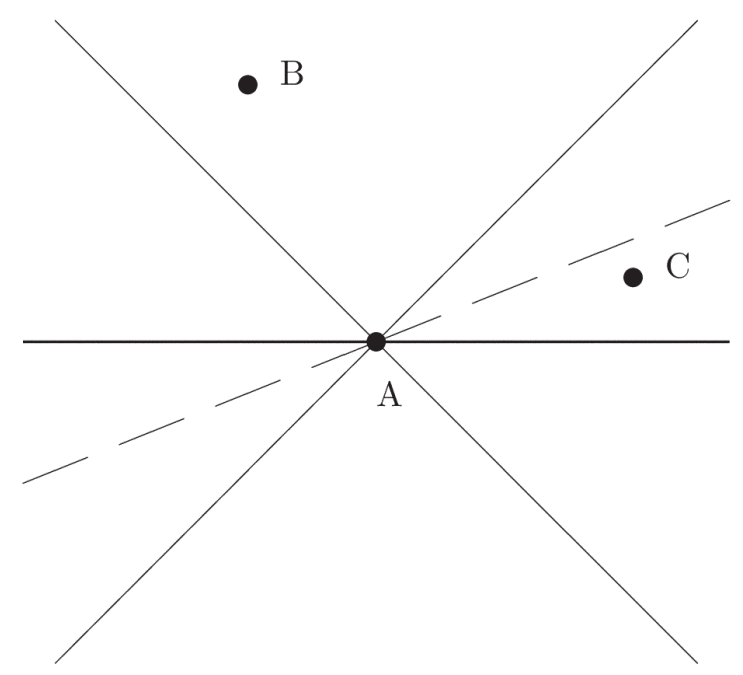

1. irudia. Minkowskiren diagrama abiadura erlatiboaz higitzen ari diren bi behatzailerentzat.

1. irudian agertzen den grafikoa Minkowski-ren diagrama da. Ardatz horizontalean $s$ tarte espaziala eta bertikalean $c t$ daude irudikaturik. Bertan A gertaeratik igarotzen diren bi fotoien unibertso-lerroak ageri dira (horizontala $45^{\circ}$-ko angeluaz mozten duten lerroak). Lerro horizontalak geldirik 
dagoen behatzailearen oraina ( $t$ konstanteko gainazala) adierazten du; lerro ez-jarraiak, berriz, behatzaile horrekiko abiadura batez higitzen ari den behatzailearen oraina. Ikus daitekeenez, oraina erlatiboa da. Gertaeren arteko espazio-denborazko distantziari so eginez, hiru kasu desberdin bereiz daitezke.

i. $\sigma^{2}>0$ bada, espazio motako tarte bat dugu (A eta C). Kasu honetan bi gertaeren arteko ordena tenporala ez da absolutua; euren abiaduren arabera, behatzaile batzuentzat A $\mathrm{C}$ baino lehenago gertatuko da, beste batzuentzat batera jazoko dira eta, azkenengoentzat, A C-ren ondoren gertatuko da.

ii. $\sigma^{2}<0$ bada, denbora motako tarte bat dugu (A eta B). Gertaera hauen ordena tenporala ez dago aldatzerik (argiaren abiaduraz baino motelago higitu behar baitira erreferentzia-sistemak), eta behatzaile guztiek B A-ren ondoren gertatzen dela ikusiko dute.

iii. $\sigma^{2}=0$ bada, argi motako tartea dugu. Gertaera hauen ordena tenporala ere absolutua da, aldiberekoak izan ahal izateko, hain zuzen argiaren abiaduraz higitzen den erreferentzia sistema bat beharko baikenuke.

Bi fotoiren unibertso-lerroek sortzen duten konoaren izena argi-konoa da. Goiko erdi konoaren barnean eta paretetan dauden gertaerek A-ren etorkizun absolutua osatzen dute (haiek A-ren efektuak izan baitaitezke). Berdin esan daiteke beheko erdi konoari buruz, A-ren iragan absolutua definituko duenaz (gertaera horiek A-ren kausa izan baitaitezke). Baina kono horretatik kanpo geratzen diren gertaerek ez dute ordena tenporal absoluturik, behatzailearen arabera A baino lehenago, ondoren edo batera jazoko baitira (gertaera horiek ezin dira A-rekin kausalki erlazionaturik egon).

Beraz, erlatibitateak erlazio kausala duten gertaeren arteko ordena tenporal absolutu bat ezartzen du. Haatik, kausalitatez ez erkaturiko gertaeren ordena tenporala erlatiboa (behatzailearen araberakoa) da. Edozein kasutan ere, irudiko etorkizuneko eta iraganeko konoak elkartrukatzeak ez du inolako eraginik erlatibitatearen legeetan. Hau da, erlatibitateren legeak, newtondar mekanikarenak bezala, denboran itzulgarriak dira. Partikulek lege hauek errespetatzen dituzte, bai denboran aurrera, bai denboran atzera.

Hurrengo urrats batean Einstein-ek erlatibitatearen legeak orokortu zituen sistema grabitatorioei aplikatzekoa zen erlatibitate orokorraren teoria eraikiz. Teoria horretatik ondorioztatzen da eremu grabitatorioek denboraren fluxua aldatzen dutela: eremu grabitatorioa zenbat eta bortitzagoa izan, denboraren fluxua motelagoa izango da. Adibidez, erloju batek lurrazalean ilargian baino astiroago funtzionatzen du. Baina efektu horrek ere ez du denboraren norantza berezi bat aukeratzen eta, beraz, erlatibitate orokorrak ere ez du denboraren gezi bat finkatzen. 
Denboraren gezia

\section{DENBORA TEORIA KUANTIKOAN}

Teoria kuantikoa uhin-funtzioaren kontzeptuan oinarritzen da. Uhinfuntzioa ezagututa sistemaz eduki dezakegun informazio guztia daukagu. Funtzio horrek uhin-ekuazioaren antzerako bat betetzen du: Schrödingeren ekuazioa deritzona. Ekuazio hori guztiz determinista da, uhin-funtzioaren eboluzio tenporala zehazki ematen baitigu. Horretaz gain, ekuazio horrek ez du iraganaren eta etorkizunaren artean desberdintzen, momentu jakin batean sistemaren uhin-funtzioa ezaguturik, berdin kalkula baitaiteke zein izango den uhin-funtzioaren forma $t$ segundo barru edo zein izan zen duela $t$ segundo. Kuantikaren emaitza fisikoak, bestalde, probabilitateen bidez ezaugarriturik daude; haiek uhin-funtzio horren interpretazio fisikoa ematean agertzen dira.

Lehen esan dugun moduan, kuantikaren bi elementu aztertuko ditugu denboraren geziarekin erlazionaturik daudenak.

Lehenengoa neurketaren interpretazioa da. Sistema kuantiko bat dugunean, neurketarik burutzen ez dugun bitartean, sistemaren uhin-funtzioa emaitza posible guztien konbinazio lineal batean dago; normalizaturik egonez gero, konbinazio linealaren koefizienteek emaitza posible bakoitzaren probabilitatea emango digute. Baina neurketa bat burutzen dugunean, Schrödinger-en ekuazioak aurresaten ez duen gertaera bat jazotzen da: uhin-funtzioaren kolapsoa. Hots, sistemak emaitza posibleen artean bat aukeratu du eta haren uhin-funtzioa guztiz aldatu da, orain neurtutako emaitza horretan egoteko probabilitatea osoa baita, gainerakoetan egotekoa nulua den bitartean. Neurketaren prozesu hau itzulezina da, sistema berez ez baita hasieran geneukan uhin-funtziora bueltatuko.

Bigarren elementua kaoiaren desintegrazioa da. Kuantikaren arabera, oinarrizko partikulen lege fisikoak ez dira gai izan behar desintegrazio baten eta haren prozesu alderantzizkoaren (emitituriko partikulen xurgapena) artean desberdintzeko. Hori frogatzeko honako hiru eragile kuantikoak erabiltzen dira:

- $C$ eragilea: karga konjugazioaren eragilea da eta prozesuan parte hartzen duten partikula guztien kargaren zeinua aldatzen du. Hots, partikula bakoitza bere antipartikularekin ordezkatzen dute.

$-P$ eragilea: alderantzikatze espaziala edo paritate eragilea da; $(x, y, z)$ koordenatuen ordez $(-x,-y,-z)$ koordenatuak ezartzen ditu.

$-T$ eragilea: alderantzikatze tenporalaren eragilea da. Denboraren norantza aldatzen du momentuetan eta spinetan aurkako zeinuak ezarriz.

$C P T$ teoremaren arabera [8], prozesu bati hiru eragile horiek aplikatzeak hasierakoa bezain baliogarria den beste prozesu bat emango liguke. Prozesu berri hori formula berdinek deskribatuko lukete. Hau da, oina- 
rrizko partikulen prozesuak aldaezinak dira $C T$ eragileen pean. Orain arte egindako esperimentu guztiek teorema hau baieztatu dute.

Teorema honek uzten du prozesuren batzuk $T$ eragilearekiko simetrikoak ez izateko aukera irekita. Izatez, prozesu bat $C P$ eragileekiko asimetrikoa eta $T$-rekiko ere asimetrikoa bada, $C P T$ simetrikoa izango da eta teorema beteko da. Beraz, $T$ simetriaren bortxaketak ere $C P$ simetriaren bortxaketa gisa uler daitezke eta, izatez, horrela bilatzen dira esperimentuetan. Horrelako bortxaketa bat lehenbiziz 1964. urtean aurkitu zen kaoi neutroaren desintegrazioan [9]. Horren ondoren, 1990. hamarkadaren amaieratik eraiki diren partikula azeleragailuetan, horrelako bortxaketak neurtu dira $\mathrm{B}$ eta $\mathrm{D}$ mesoien desintegrazioetan ere.

$K_{L}^{0}$ kaoi neutroak hiru desintegrazio posible dauzka $\pi$ pioi deituriko partikuletan:

$$
\begin{aligned}
& K_{L}^{0} \rightarrow \pi^{0}+\pi^{0}+\pi^{0}, \\
& K_{L}^{0} \rightarrow \pi^{+}+\pi^{-}+\pi^{0}, \\
& K_{L}^{0} \rightarrow \pi^{+}+\pi^{-} .
\end{aligned}
$$

Froga daiteke lehen bi desintegrazioek $C P$ simetria dutela eta, beraz, $C P T$ simetria izateko, $T$-simetrikoak ere izan behar dute. Hau da, lehen bi desintegrazio horiek prozesu itzulgarriak dira, denboran simetrikoak diren legeen pean baitaude. Baina hirugarren desintegrazioak ez du $C P$ simetriarik; beraz, $C P T$ simetria izateko, $T$-rekiko asimetrikoa izan behar da. Hor agertzen zaigu denboraren gezi mikroskopikoa.

Edonola ere, $T$ bortxaketa hauek oso gutxitan agertzen dira, probabilitate oso baxua baitute gertatzeko. Hemen azaldu dugun adibidean, kaoiaren desintegrazio hori \%0,1eko probabilitateaz gertatzen da [8]. Beraz, nahiz eta gertaera hauek denboraren gezi bat definitzen duten, gezi horren norantza ez da besteak bezain argia. Posiblea balitz pelikula batean prozesu mikroskopiko hauek grabatzea eta atzekoz aurrera behatzea, oso momentu gutxitan konturatuko ginateke denboran atzerantz doan filme bat ikusten ari garela.

Bi gertaera hauek gorabehera, kuantikaren legeak denboran simetrikoak dira. Hemendik aurrera atomo edo molekulen higidura aztertu behar dugunean, mekanika klasikoa erabiliko dugu, nahiz eta jakin deskribapen egokiena kuantikoa dela. Hala ere, garrantzitsuena, ikusiko dugun moduan, partikulen higidura deskribatzen duten legeak denboran simetrikoak direla izango da; makroprozesuetan, berriz, lege asimetrikoak agertuko zaizkigun bitartean. 
Denboraren gezia

\section{DENBORA TEORIA ELEKTROMAGNETIKOAN}

Fisikaren oinarrizko lege guztiak bezala, elektromagnetismoko Maxwell-en ekuazioak simetrikoak dira denboran. Haietatik abiatuz, uhin-ekuazioa lortzen da uhin elektromagnetikoentzat. Ekuazio horrek bi soluzio desberdin onartzen ditu: etorkizunerantz hedatzen den uhina (igorletik infiniturantz dibergitzen duena) eta iraganerantz hedatzen dena (infinitutik etorrita igorlean konbergitzen duena). Kausalitatea errespetatzeko, iraganerantz doan uhina gure teoriatik kanpo bidaltzen dugu eskuz; bestela, kargabanaketa batek, espazioko puntu batean kokatu aurretik, puntu horretatik edozein distantziara sortuko luke eremua. Horregatik deskribatzen ditugu eremuak potentzial atzeratuen bidez eta kentzen ditugu eskuz aurreratuen soluzioak. Hau da, karga-banaketa batek eremua sortuko du harengandik distantzia jakin batera, argiak distantzia hori ibiltzeko behar duen denbora igaro denean soilik. Horrelaxe, guk, eguzkia begiratzean, duela zortzi minutu zegoen posizioan ikusten dugu, eta ez zortzi minutu barru egongo den posizioan. Hau guztia, nabari daitekeenez, erlatibitate-teoriako argiaren abiadura finitoagatik gertatzen da.

Erradiazioaren denboraren gezia ulertzeko azaldu behar dugu zergatik bonbillek beren baitatik dibergitzen duten uhinak soilik bidaltzen dituzten eta ez beren baitara konbergitzen dutenak; izan ere, gure teoria elektromagnetikoak biak onartzen ditu. Badago aukera bat kolapsatzen duten uhin horiek kausalitatearen aurka ez joateko, soilik baldin eta uhin horiek beste igorle batzuek igortzen badituzte. Adibidez, gerta daiteke gela bateko pareta guztiek argia modu oso berezi batean igortzea eta eragin guztien batura gelaren erdian dagoen bonbillan kolapsatuko den uhin konbergentea izatea; gertaera horrek ez luke fisikaren inongo legerik kontraesango eta uhin hori bonbillak iraganerantz igorritako uhin baten baliokidea litzateke. Bi azalpen daude halakorik gerta ez dadin.

Lehenengoa, gertaera hori posibletzat ez onartzea da, jazotzeko dagoen probabilitate ia nuluagatik; izan ere, oso zaila baita paretetako atomo guztiak argia modu berezi horretan igortzen hastea. Termodinamikaren bigarren legeak onartzen ez dituen konportamenduen baliokidea dugu hau.

Baina badago Wheeler eta Feynman-i zor diegun erradiazioaren denboraren geziaren beste azalpen bat [10]. Haien arabera, iturri batek igorpena egiten duenean, bai etorkizunerantz bai iraganerantz igortzen du, teoriak aurresaten duen moduan. Proposatu zuten etorkizunerantz bidaltzen den uhina azkenean materialen batek (etorkizuneko xurgatzailea) xurgatuko zuela. Hori gertatuz gero, material horren atomoek uhina berrigorriko zuten denboraren bi norantzetan. Azkenean, iraganerantz doazen bi uhin lortzen ditugu: hasierako igorleak iraganerantz bidalitakoa eta etorkizuneko materialak bidalitakoa. Wheeler eta Feynman-ek frogatu zuten bi uhin horiek elkar deusezten zutela interferentzia deuseztatzailearen bidez. Etorki- 
zuneko elementu xurgatzailetik datorren uhinak igorleak etorkizunerantz bidalitako uhinarekin konstruktiboki interferitzen du. Horrela, azkenean, etorkizunerantz doan uhin bakarra lortzen dugu. Azalpen korapilotsuegia dirudi honek soilik etorkizunerantz hedatzen den uhin bat lortzeko, baina teoria elektromagnetikoaren aurresanak guztiz kontuan hartzen baditugu (bai iraganerantz, bai etorkizunerantz igortzen dela) hain zuzen esperimentalki ikusten dena ondorioztatzen du, hots, uhinak soilik etorkizunerantz igortzen direla. Teoria horren hipotesi bakarra etorkizunean elementu xurgatzailea existitzea da.

\section{DENBORA TERMODINAMIKAN}

Newton-en garaitik bazegoen finkaturik termodinamikaren lehen legea: sistema isolatu baten energia osoa konstantea da; hots, energia formaz aldatzen da baina ez da galtzen, ezta sortzen ere. Eta, izatez, mekanikaren prozesu guztiek lege hau onartzen dute.

Baina prozesu jakin bat gertatuko den ala ez jakiteko ez zaigu nahikoa lege horrekin, zeren, pilota batek lurreko beroa xurgatu eta bote egiten hasiz gero, energia kontserbatuko litzateke, baina oraindik ez dago halako prozesurik ikusi duen inoren berririk.

Eman dezagun tenperatura desberdinean dauden bi gorputz elkartzen ditugula, edo karga desberdina duten bi eroale, edo grabitatearen eraginez altuera batetik ur kopuru bat erortzen dela. Termodinamikaren lehen legeak dioenez, prozesu horietan guztietan energia osoa kontserbatuko da, baina horretaz gain, beste gauza garrantzitsu bat galduko da bidean: lan erabilgarria ekoizteko gaitasuna. Bi gorputzen arteko tenperatura-diferentzia existitzen den bitartean, diferentzia edo desoreka hori lana egiteko erabil daiteke, adibidez termopare baten bidez korrontea sortuz. Bi eroaleen artean kable bat jartzearekin nahikoa zen korrontea sortzeko. Edo posible zen ur jauziak erorketan zehar irabazitako momentu lineala errota bati transferitzea. Baina aldaketak jazo ostean, ezinezkoa da sistematik lana ateratzea, bi gorputzek tenperatura bera baitute, bi eroaleek potentzial berbera, eta urak bere energia galdu duelako beheko lurraren aurka talka egitean.

\subsection{Orekaren termodinamika}

Orekaren termodinamikaren bigarren legeak bi enuntziatu, desberdin baina baliokide, onartzen ditu:

- Clausius: ezin da beroa tenperatura baxuagoko gorputzetik tenperatura altuagokora pasa lanik egin gabe.

- Kelvin-Planck: ezin da bero kantitate bat osorik lan bihurtu. 
Bi enuntziatuak erlazionatzeko Clausius-ek $d S$ entropia aldaketa infinitesimala definitu zuen [11]:

$$
d S=\left(\frac{\delta Q}{T}\right)_{\mathrm{itzulgarri}}
$$

non $\delta Q$ hasierako eta amaierako egoerak elkartzen dituen prozesu itzulgarri batean zehar sistemak xurgaturiko beroa den, eta $T$, tenperatura absolutua. Kontzeptu hau erabiliz aipaturiko bi enuntziatuen ondorioa berbera zela erakutsi zuen Clausius-ek: sistema isolatu baten entropia ez dela inoiz murrizten.

Azken finean, lege horrek ziurtatzen du desoreka guztiak orekatuko direla, honela lanerako erabilgarria zen energia degradatuz (oro har bero bihurtuz). Hau ikusirik, entropia desoreka falta moduan irudika dezakegu. Askotan entropiari desordenaren zentzua ematen zaio: beste energia mota batzuk ez bezala, beroa energia desordenatua da, energia termikoaren eragina atomo edo molekulen bibrazio aleatorioa baita.

Prozesu bat gertatu ondoren sistema isolatu baten entropiak konstante badirau, prozesu hori itzulgarria dela diogu. Horrek esan nahi du prozesuak atzerako bidea egin dezakeela, sistema hasieran zuen egoeraraino bueltatuz inolako aldaketa netorik gabe. Prozesu hauek denboran simetrikoak dira eta ezin dute denboraren gezirik finkatu. Prozesuok gertatzeko ez da energia-barreiaketarik egon behar eta kuasiestatikoki gertatu behar dira.

Prozesuaren ondorioz entropia handitzen bada, ezinezkoa izango zaio sistemari hasierako egoerara bueltatzea kanpo-eraginik gabe. Prozesu hauek itzulezinak dira, eta benetan gertatzen diren prozesuak dira, praktikan beti baitago energia barreiaketaren bat eta ezinezkoa baita kuasiestatikotasuna lortzea.

Azken prozesu hauek bai ezartzen dute asimetria bat denboran: norantza batean entropiaren handipena baitugu eta bestean murrizketa. Beraz, honela defini daiteke denboraren norantza: entropia handitzen denekoa.

Lehenago esan dugun moduan, termodinamikaren legeak funtsezkotzat jo izan dira historian zehar; izan ere, entropiaren handipena egunero ikusten dugu: zigarroak hauts bilakatu arte erretzen dira, baina hautsa ez da inoiz berez zigarro bilakatuko; marruskadura dela eta, piloten higidura balaztatzen da, ez da azeleratzen, eta abar.

Beraz, sistemaren orekako egoera entropia maximokoa izango da, orduan ez baita aldaketa gehiagorik gertatzeko aukerarik egongo. Entropiaz gain, beste potentzial termodinamiko batzuk defini daitezke, hala nola Gibbs-en edo Helmholtz-en energia askea edo entalpia. Sistemaren mugal- 
de-baldintzen arabera, potentzial termodinamiko batzuen edo besteen muturrek (maximo edo minimoek) finkatuko dute sistemaren orekaren posizioa. Adibidez, presio konstantepean gertatzen den erreakzio kimiko bat orekara helduko da bere entalpia minimoa eta entropia maximoa lortzen duenean. Orekarako joera honek finkatzen du beraz denboraren geziaren xedea.

Baina potentzial horiek guztiak soilik orekan defini daitezke. Orekako termodinamika deituriko honetan, beti gaude orekatik infinitesimalki hurbil, prozesu osoan zehar potentzial termodinamikoak definitu ahal izateko. Formalismo hau soilik eboluzio termodinamikoaren azkenengo egoeraz arduratzen da, desoreka makroskopiko guztiak berdindurik dauden puntuan. Sistemak non amaituko duen esaten digu, baina tarteko pausoei buruz ez digu inolako informaziorik ematen. Izatez, formalismo honen bidez prozesuren bat aztertu nahi dugunean, egoera funtzioek bidearekiko menpekotasunik ez dutela gogoratuz, sistemaren hasierako eta amaierako egoerak ibilbide itzulgarrien bidez elkar daitezke, eta horietan zehar lehen agertu zaigun entropiaren formula erabil daiteke.

Beraz, denboran asimetria bat finkatzen duen lege bakarra izan arren, termodinamikaren bigarren lege honek, formalismo honetan behintzat, sistemaren eboluzio eta aldaketa guztiak gainetik pasatzen ditu, soilik sistema norantz doan esanez. Denboraren aurrerabidea hobeto ezagutzeko asmoz, tarteko pausoak ezagutu nahi ditugu.

\subsection{Ez-orekaren termodinamika}

Ez-orekaren termodinamika bitan bana daiteke: bertsio lineala (orekatik oso urrun ez dauden prozesuak aztertzeko) eta bertsio ez-lineala (orekatik oso urrun dauden prozesuez arduratzen dena).

Sistema ireki batean, alegia, entropia eta materia ingurunearekin aldatzeko gai den batean, entropiaren aldaketa bitan bana dezakegu:

$$
d S=d_{e} S+d_{i} s,
$$

$d_{e} S$ entropiaren fluxua (sisteman ingurunetik sartzen edo irteten dena) eta $d_{i} S$, prozesu itzulezinak direla eta, sisteman ekoizten den entropia delarik.

Termodinamikaren bigarren legeak ziurtatzen digu barne-prozesuak direla eta sisteman sortzen den entropia positiboa dela,

$$
\frac{d_{i} S}{d t} \geq 0 .
$$

Sisteman oreka lokala, hots, bolumen-elementu txiki batentzat (txikia termodinamikoki; hau da, bere barnean oraindik limite termodinamikoan 
aritzeko adina partikula dauzkana) orekako termodinamika erabil dezakegula onartuz, denboran zeharreko entropia-ekoizpena honela idatz dezakegu:

$$
P=\frac{d_{i} S}{d t}=\sum_{k} J_{k} F_{k},
$$

non $J_{k} k$-garren prozesu itzulezinari dagokion fluxua dugun eta $F_{k}$, berriz, indar orokortua den. Indar orokortu hauen adibideak tenperatura, potentzial kimikoa eta potentzial elektrikoaren gradienteak dira. Eta horietako bakoitzari fluxu bat dagokio, aurrekoekiko hurrenez-hurren: beroa, masa eta karga fluxua.

\subsubsection{Orekatik nahiko hurbil: erregimen lineala}

Orekatik nahiko gertu gaudenean fluxuek indarrekiko menpekotasun lineala dutelako hurbilketa egin daiteke:

$$
J_{k}=\sum_{i} L_{k i} F_{i},
$$

non $L_{k i}$ koefiziente esperimentalak izango diren. Aipatu beharra dago $i$ motako indar batek $k$ motako fluxu bat sor dezakeela; hots, indarrak eta fluxuak nahasten dira eta ez dauzkate efektu zuzenak soilik. Adibidez, termodifusio fenomenoan (Soret efektua) tenperatura-gradiente batek masaren garraioa sor dezake, bero garraioaz gain; azkenengo hori baita tenperatura gradienteari dagokion zuzeneko efektua.

Erregimen lineal honetan Prigogine-k frogatu zuen sistemaren $P$ entropia-ekoizpena potentzial termodinamiko baten moduan uler daitekeela. Oro har, sistemak egoera geldikor baterantz eboluzionatuko du, zeinean $P$ minimoa izango den. Egoera horretan termodinamikaren bigarren legea betetzen da, unibertsoaren entropia handituz baitoa, baina sistemak ekoiz dezakeen entropia minimoa ekoizten egongo da. Sistemak, bere bizi-denbora ahal bezain beste luzatzeko, minimora jaisten du entropia-ekoizpena.

Aurreko atalean azaldu dugun moduan, orekako termodinamikan denboraren geziaren xedea potentzial termodinamikoen muturrak dira (batzuentzat minimoa eta besteentzat maximoa, sistemaren mugalde-baldintzen arabera). Orekatik kanpoko sistemetan, erregimen linealean, antzerako zerbait dugu. Kasu horretan minimizatzen dena entropia-ekoizpena da eta azkenengo egoera geldikorra da; hots, orekaren baliokidea, baina sistemaren desoreka ezereztu beharrean konstantea izango da. 
Jar dezagun adibide bat: lehen aipaturiko termodifusioaren prozesua. Demagun bi gas desberdin dauzkagula tenperatura konstantean dagoen kutxa batean nahasturik. Momentu batean tenperatura-gradiente bat ezartzen dugu kutxaren alde batetik bestera, eta kanpo eraginez, gradiente hori finko mantentzen dugu. Pixkanaka-pixkanaka molekulak era asimetrikoan kokatzen hasiko dira, kontzentrazio-gradiente bat sortuz: molekula arinen proportzio handiagoa kokatuko da tenperatura altuagoko aldean, eta pisutsuenen proportzio handiagoa izango dugu tenperatura baxuagoko aldean. Denbora tarte bat pasa ondoren egoera geldikorra lortuko dugu, kontzentrazio-gradientea denboran konstante mantenduko den bitartean.

Kasu honetan, nolabaiteko ordena lortu dugu sisteman, hasierako egoera azkenengoa baino desordenatuagoa irudi dakigukeelako. Baina hemen ere bigarren legea betetzen da eta horrek entropiaren handipenak ez duela unibertsoaren degradazio monotoniko eta uniformea esan nahi ikuskatzera garamatza. Aipatuko dugun moduan, orekatik urrunago dauden sistemetan ordena askoz altuagoko sistemak ager daitezke. Horrela, ondorioztatu ahal izango dugu autoantolaketa ez dagoela kontraesanean termodinamikak ezarritako denboraren geziarekin.

\subsubsection{Orekatik urrunago: erregimen ez-lineala}

Ikusi dugun moduan, erantzun lineal bat daukaten sistemetan posiblea izan da printzipio bariazional bat definitzea entropia-ekoizpenaren minimo gisa. Denboraren gezi bat definitzen digu horrek. Printzipio hau orekatik perturbazio txikien bidez ateratzen ditugun sistemei aplikatzen zaie. Perturbazio horiek txikiak ez direnean, kontua oso bestelakoa da. Izatez gaur egun oso urrun gaude oraindik orekatik kanpoko sistema orokorrak ulertzetik. Sistema horietan ez da ezagutzen - eta zenbait zientzialariren aburuz ezinezkoa da definitzea - printzipio bariazional orokor bat. Hau da, magnitude fisiko bat zeinen muturrek sistemaren eboluzioaren norantza emango digun. Saiakera asko egon dira horietako printzipio bariazionalak definitzeko eta haien arabera teoriak eraikitzeko, baina printzipio horiek guztiak ez dira unibertsalak, hots, ezin zaizkio edozein sistemari aplikatu.

Horrez gain, orekatik urruneko kasu hauetan ez daukagu fluxua eta indarrak erlazionatzen dituen ekuaziorik; eta Prigogine-ren teorema ere ez da erabilgarria. Puntu batetik aurrera (puntu kritikoa deritzona), aipaturiko egoera lineal geldikorra ez-egonkorra bihurtzen da, sistemaren diagrama adarkatzen da eta egoera egonkor berriak eta desberdinak agertzen dira. Oro har, orekatik urrun dagoenean, sistemak ez dauka egoera egonkor bakarra, erregimen linealean bezala, haietako ugari baizik.

Egoera horien artean ordena oso altukoak aurki ditzakegu, zeinetan milioika molekulak euren mugimenduak espazioan zein denboran koordinatzen dituzten. Honen adibide argia erloju kimikoak dira, zeintzuek eu- 
ren kolorea periodo zehatz batekin aldatzen duten. Belousov-Zhabotinsky erreakzio kimikoek, hala nola Rayleigh-Benard konbekzioak, egitura espazialak eratzen dituzte. Egitura hauei Prigogine-k egitura barreiatzaile izena jarri zien, sistemaren eta ingurunearen arteko materia- eta energia-trukearen ondorioz sortzen baitira [4].

Aipaturiko prozesu guztietan entropia osoa handitzen da eta, beraz, termodinamikaren bigarren legeak ez du autoantolaketa baztertzen. Honela, egitura ordenatuen existentziak (izaki bizidunak, izar-sistemak...) ez du bigarren legearekin kontraesanik ez eta lege horrek erakutsi digun denboraren norantzarekin.

\section{ITZULEZINTASUNAREN PARADOXA}

Mundu mikroskopikoko partikulen higidura mekanika edo kuantikaren lege itzulgarriek azaltzen dute. Baina mundu makroskopikoranzko bidean, termodinamika erabilgarria bihurtzeko adina partikula elkartzen ditugunean, denboraren gezia agertzen zaigu. Nola izan daiteke, lege itzulgarrietatik abiatuz, partikula taldeak kontuan hartzean, denboran asimetria bat agertzea? Non dago mundu mikroskopikotik makroskopikorako jauzia?

Bi teorien arteko kontraesan honek mekanika eta termodinamika, kasurik hoberenean, teoria amaitugabeak direla baieztatzera garamatza.

Paradoxa hau itzulezintasunaren paradoxa edo Loschmidt-en paradoxa izenaz da ezaguna. Hau argitu nahian, bi munduak (mikroskopikoa eta makroskopikoa) erlazionatzen dituen teoria berrikusiko dugu: mekanika estatistikoa. Hainbat saiakera egin dira itzulgarritasunetik itzulezintasuna ondorioztatzeko asmoz. Horietariko lehena Boltzmann-ek proposatu zuen H teorema izan zen [12]; baina, ikusiko dugun moduan, teorema horrek arazoa eskuz konpontzen du, beti baliogarria ez den hurbilketa bat erabiltzen baitu. Izatez, Loschmidt-ek Boltzmann-en proposamena kritikatzean idatzi zuen artikulua [13] izan zen paradoxa honi bere izena eman ziona. Ildo beretik, gaur egun egile askok paradoxa honen konpontzaile moduan ulertzen duten teorian aztertuko dugu: kaos dinamikoa.

\subsection{Mekanika estatistikoa}

Mekanika estatistikoaren teoriak informazio mikroskopiko osoa (partikula bakoitzaren energia edo abiadura) mikroegoeren zenbaketara laburtzen du. Mikroegoera bat, mekanika klasikoaren ikuspuntutik, partikula bakoitzaren energia edo abiadura ezagutzea da. Kuantikaren ikuspuntutik, sistemaren mikroegoera ezagutzea partikula bakoitzaren uhin funtzioa ezagutzea da. Makroegoera bat, berriz, sistemaren magnitude makroskopikoak (tenperatura, presioa, bolumena...) ezagutzea da. Makroegoera bakoitzari 
mikroegoera asko dagozkio; adibidez, gas baten presio eta tenperatura jakin batentzat, partikula-proportzio jakin bat izango dugu abiadura jakin desberdinekin, baina berdin dio partikula zehatz batek duen abiadura zein den.

Boltzmann-en formulak makroegoera bati dagokion entropia makroegoera berari dagokion mikroegoeren kopuruarekin $(\Sigma)$ erlazionatzen du:

$$
S=k_{B} \ln \Sigma,
$$

non $k_{B}=1.38 \times 10^{-23} \mathrm{~J} / \mathrm{K}$ Boltzmann-en konstantea den. Horren arabera, entropia maximizatzearen baliokidea $\Sigma$ maximizatzea da; hots, orekako egoera mikroegoera gehien dagozkion makroegoera izango da. Mikroegoera bakoitzaren probabilitatea berbera dela suposatuz, oreka egoera probableena gisa uler dezakegu. Hau da, sistemak probabilitate baxuko egoeratik probabilitate maximoko egoerarantz eboluzionatzen du.

Ez-orekaren mekanika estatistikoan $\rho$ probabilitate-banaketa funtzioa erabiltzen da (mekanika klasikoa erabiliko dugu, baina kuantikak emaitza berberetara garamatza); honen esanahia erakusteko defini dezagun fase-espazioa. $N$ partikulen fase-espazioa sistemaren partikula guztien $q_{i}$ posizio eta $p_{i}$ momentuek osatzen duten espazioa da, $i=1, \ldots, N$ izanik. Fase-espazioaren dimentsioa $\partial N$ da, partikula bakoitza karakterizatzeko posizioaren hiru osagai eta momentuaren beste hiru osagaiak behar baititugu. Beraz, sistemaren partikula guztien posizio eta momentuak ezagutzeko, nahikoa zaigu sistema fase-espazioko zein puntutan dagoen jakitea. Probabilitatebanaketa funtzioaren balioak fase-espazioko puntu batean $\rho\left(p_{i}, q_{i}\right) d q^{N} d p^{N}$ sistema puntu horren inguruko $d V=d q^{N} d p^{N}$ hiperbolumen infinitesimalean aurkitzeko probabilitatea emango digu. Funtzio horrek Hamilton-en mekanikaren formuletatik (hauek Newton-en ekuazioak baino ez dira, beste formalismo batean emanik) ondoriozta daitekeen Liouville-ren ekuazioa betetzen du:

$$
\frac{\partial p}{\partial t}=\sum_{i=1}^{N} \frac{\partial \mathcal{H}}{\partial p_{i}} \frac{\partial \rho}{\partial q_{i}}-\frac{\partial \mathcal{H}}{\partial q_{i}} \frac{\partial \rho}{\partial p_{i}}
$$

$\mathcal{H}$ sistemaren Hamiltondar funtzioa delarik. Argi ikus daiteke Liouville-ren ekuazioa, mekanikaren lege guztien moduan, denboran simetrikoa den hamiltondar funtzioa duten sistemetarako simetrikoa dela. Gogoratu $t \rightarrow-t$ aldaketa egitean, $p$ momentuek ere zeinuz aldatzen dutela.

Sistemaren fase-espazioko hasierako $\left(q_{0}, p_{0}\right)$ puntua zehazki ezagutzen badugu, Newton edo Hamilton-en ekuazioak erabiliz haren eboluzioa azter dezakegu. Ziurgabetasunen bat badago, haren probabilitatearen fluxua kalkulatu ahal izango dugu Liouville-ren ekuazioaren bidez. Ekuazio horrek 
bidea zabaltzen digu orekaz kanpoko entropia definitzeko; izan ere, orekan, ondoko definizioa dugu:

$$
S=-k_{B} \int_{V} \rho \ln \rho d V
$$

$d V$ lehen definituriko fase-espazioko bolumen elementua delarik. Baina definizio hori ezin da hedatu orekatik kanpoko entropia definitzeko, Liouville-ren ekuazio bera erabil baitaiteke magnitude hori denboran konstante mantentzen dela frogatzeko:

$$
\frac{\partial S}{\partial t}=0 .
$$

Eta hori, noski, termodinamikaren bigarren legearen aurka doa.

\subsection{Paradoxaren erantzun posibleak}

\subsubsection{Boltzmann-en H teorema}

Boltzmann-ek, Liouville-ren ekuazioa hurbilduz, orekatik kanpo entropia definituko zuen magnitude bat lortu zuen, eta honela itzulezintasun bat ondorioztatu zuen Liouville-ren ekuazio itzulgarritik [12]. Honetarako, kaos molekularra deituriko hurbilketa aplikatu zuen. Haren arabera, sistema osatzen duten partikulen arteko talkek lehenago existitzen ez diren partikula horien arteko korrelazioak sortzen dituzte. Hau da, talka baino lehen partikulak guztiz independenteak dira; baina talkaren ondoren euren artean koerlazionaturik daude.

Demagun $f(\vec{v}, t) d^{3} v$ dela gas baten partikulen abiaduren probabilitate-banaketa. Egoera orokorrean, probabilitate hauek - esplizituki adierazi den moduan - denboraren funtzioak dira. Eta haien bidez honako funtzioa defini daiteke:

$$
H(t)=\int_{v} f(\vec{v}, t) \ln f(\vec{v}, t) d^{3} v
$$

non $d^{3} v$ abiaduren espazioko bolumen elementua den. Hau da, abiadura posible guztietarako integratu behar da.

Abiaduren probabilitate funtzioaren $f(\vec{v}, t)$ eboluzioa denboran ezagutzeko Liouville-ren ekuazioa erabiltzen da. Bi partikularen arteko talka aztertzean, talkaren aurretik bi partikulak independenteak direla suposatu zuen Boltzmann-ek. Matematikoki horrek esan nahi du $\rho$ probabilitatebanaketa partikula bakoitzaren probabilitate-banaketen $f_{1}$ eta $f_{2}$-ren biderkadura dela. Baina talkak biak korrelazionatzen ditu, eta haren osteko $f_{1}$-en 
eboluzioan $f_{2}$ agertzen da. Modu honetan froga daiteke goian definituriko $H(t)$ funtzio horrek honako desberdintza betetzen duela:

$$
\frac{\partial H}{\partial t} \leq 0 .
$$

Aurreko atalean ikusi dugun orekako entropiaren definizioa gogoratuz, orekan

$$
S_{\text {oreka }}=-k_{B} H_{\text {oreka }}
$$

dugu. Beraz, $H(t)$ funtzioa erabil daiteke orekaz kanpoko entropia zuzenean definitzeko:

$$
S=-k_{B} H
$$

Honela, Liouville-ren ekuazio itzulgarritik abiatuz, Boltzmann-ek denboran asimetria bat finkatzea lortu zuen ( $H$ funtzioak etengabe murriztuzjoan behar baitu denborak aurrera egin ahala). Baina asimetria hau eskuz sarturikoa da: kaos molekularraren hipotesiak sartzen du. Hipotesi hori ez da denboran simetrikoa, talka gertatu baino lehen partikulak ez baitaude korrelazionaturik, baina bai ondoren. Suposizio hori ona da gas diluituetan, baina ez dago sistema orokorragoetara hedatzeko modurik.

\subsubsection{Kaos dinamikoa}

Demagun sistema baten probabilitate-distribuzioan 2 irudiko itxuraldaketa gertatzen dela. Hamilton-en ekuazioak erabiliz, A eta A'-k bolumen bera dutela froga daiteke. Emaitza hau Liouville-ren teorema izenaz da ezaguna. Higidura hori fluido batenarekin erkatuz, esan dezakegu $\varrho$ probabilitate-banaketa fluido konprimaezin baten modura higitzen dela faseespazioan zehar.

1889. urtean Poincare-k erakutsi zuen hiru gorputzen problema integraezina zela; hots, ez zuela soluzio analitikorik. Honela ateak ireki zizkion kaos dinamikoaren teoriari eta kolpea eman zion Newton-en mekanikaren determinismoari .

Kaos dinamikoa sortzen da hasierako baldintzekiko menpekotasun handia duten sistemetan; hau da, hasierako baldintza berdintsuko bi sistemaren eboluzioek esponentzialki dibergitzen dutenean. Hau gertatzeko, sistemaren higidura-ekuazioek ez dute linealak izan behar. Ekuazio linealen kasuan, hasierako baldintza parekoek eboluzio parekoetara daramatzate, baina ez-linealtasunak desberdintasun txikiak anplifika ditzake. Hau ikuskatzeko, pentsa dezagun gas batean zehar higitzen ari den atomo baten 


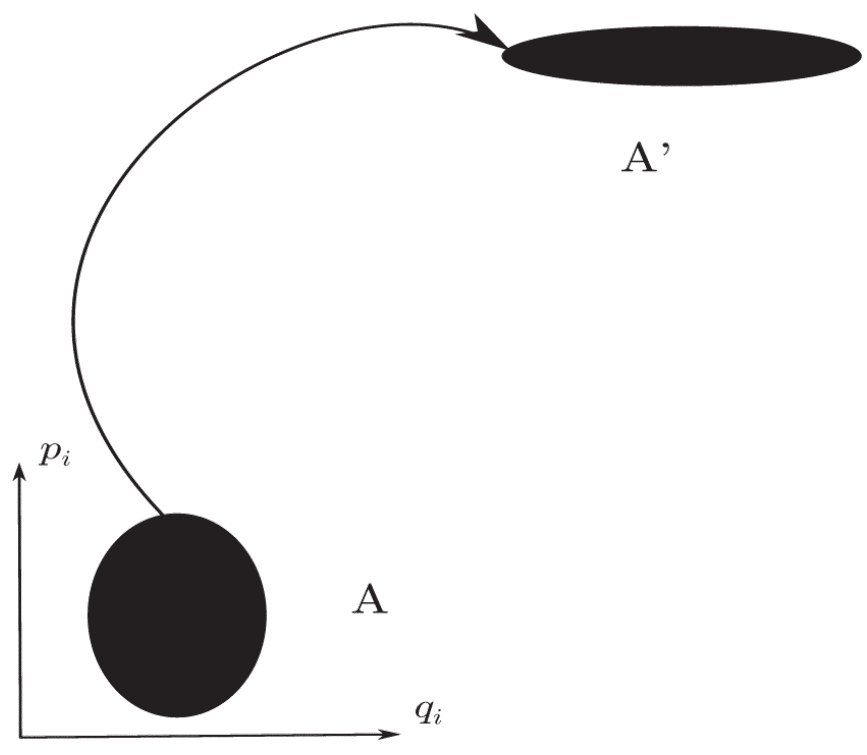

2. irudia. Liouville-ren teoremaren arabera A eta A'-k bolumen berbera dute.

higiduran. Haren hasierako baldintzak pixka bat aldatuz, beste partikula batekin talka gertatuko zen lekuan jada ez da gertatuko eta beste partikula batzuekin izango da talka.

Beste alde batetik, ezinezkoa da mundu errealean hasierako baldintzak zehaztasun osoz ezagutzea; errore minimoa Heisenberg-en ezagutza ezaren printzipioak emango digu. Baina praktikan ez da beharrezkoa hain errore txikiak aintzat hartzea, gure tresna-erroreak hori baino askoz handiagoak baitira. Ezagutza eza hori dela eta, sistema fase-espazioan dimentsiodun hiperesferatxo baten bidez adierazi behar dugu, eta ez puntu baten bidez.

Oro har, sistema lineal batean txiki mantentzen da hasierako ezagutza gabezia txiki bat. Hau da, hasieran sistema hiperesferatxo txiki baten bidez karakterizaturik badago, uneoro hiperesferatxo hori txikia izango da. Sistema ergodikoa bada fase-espazioko puntu guztietatik pasako da denbora nahiko utziz gero, baina ibilbidea guztiz zehazturik egongo da. Bestalde, sistema kaotikoek hasierako esferatxo txikia eboluzionaraztean, probabilitate-banaketa adarkatzen joango da fase-espazioko puntu guztiak betetzen dituen bitartean.

Pentsa dezagun perfume-botila bat gela batean zabaltzen dugula; orduan perfume-molekulak botilatik irteten hasiko dira gela osoa bete arte. Horren deskribapena fase-espazioan parekoa da: hasieran esferatxo txiki baten bidez adierazten dugu sistemaren egoera, molekula guztiak botilaren barnean baitaude. Beraz, hasieran botilatik kanpo egoteko probabilita- 
tea nulua da. Denbora pasa ahala botilatik kanpo egoteko probabilitate handitzen doa, botilaren barnean jaisten doan bitartean, azkenean gela osoan zehar uniformea izan arte. Hori gertatzen ari den bitartean, fase-espazioan probabilitate distribuzioa adarkatzen doa eskuragarria den fase-espazio osoa bete arte. Orduan, jada ezin denean aldaketa gehiagorik jazo, orekan egongo gara eta sistemak probabilitate berbera edukiko du fase-espazioko edozein puntutan egoteko.

Nahiz eta probabilitate-distribuzioa adarkatu, Liouville-ren teoremaren arabera haren bolumenak konstante iraun behar du. Beraz, orekan makroskopikoki era homogeneoan banaturik agertuko zaigun arren, mikroskopikoki begiraturik, printzipioz distribuzioa homogeneotasunik urrun egongo da.

Beste alde batetik, badakigu praktikan ezinezkoa dela sistema guztiz isolatu bat edukitzea, sistemaz kanpoko partikulen eragin aleatorio desberdinek (adibidez eragin grabitatorio eta elektromagnetikoek) sistemaren barneko partikulen arteko korrelazioak apurtzen baitituzte. Kasu honetan sistemaren eboluzio zehatza ezin denez kalkulatu une batean duen egoera ezagutuz, probabilitate-distribuzioa ez da konprimaezina izango. Horregatik, probabilitate-distribuzioa benetan gas baten moduan hedatzen da faseespazio osoa uniformeki betez.

Hau da, beraz, kaos dinamikoa itzulgarritasunaren paradoxaren erantzuna dela ikusten dutenen ikuspuntua [14]. Sistemako partikulen higidura guztiz korrelazionaturik dago; hau da, une batean sistemako partikula guztien posizioa eta momentua ezaguna bada, mekanikaren ekuazioak erabiliz, sistemaren eboluzio osoa kalkula genezake, bai denboran aurrera zein atzera. Baina saihestezinak diren ausazko kanpo-eraginak direla eta, sistema mekanikaren legeek aurresandako eboluziotik aldentzen doa, haren eboluzioari aukera gehiago zabaltzen baitzaizkio. Hots, sistemak ezin ditu bere aurreko egoerak gogoratu, ausazko eragin batzuek beraren gain eragin izan dutelako. Azkenean, sistemaren probabilitate distribuzioa benetan uniformea da fase-espazioko puntu guztietan.

Alde batetik, hastapen-baldintzetan izango ditugun nahitaezko erroreak eta, bestetik, gure sistemaren gaineko ausazko kanpo eraginek, teorikoki izan genezakeen determinismoa apurtzen dute eta ezinezkoa bihurtzen dute sistemaren eboluzioa guztiz zehaztea. Modu honetan, mikroskopikoki guztiz determinista den teoria batetik sistema makroskopikoak ezaugarritzen dituen itzulezintasuna berreskuratzen dugu.

Baina hainbat zientzialariren aburuz (ikus adibidez [15]), kaos dinamikoak egiten duen bakarra arazoa lekuz aldatzea da. Zeren eta, ausazko eragin horiek ezagutzeko gai bagara? Orduan haien eragina kontuan hartu ahal izango genuke, berriro sistemaren iragana eta etorkizuna kalkulagarri bihurtuz, hastapen-baldintzetako errore saihestezinak gorabehera. 
Denboraren gezia

\section{PARADOXARI BUELTA EMATEN: BEHARREZKOA AL DA ENTROPIAREN HANDIPENA AZALTZEA?}

Gehienetan zientzian eta filosofian aurrera egiteko, funtsezkoena galdera aproposak egitea da. Artikulu honetan zehar gure zentzumenen bidez hain naturala iruditzen zaigun denboraren geziari oinarri fisiko bat bilatzen saiatu gara. Eta, ikusi dugunez, denboraren gezi hori hoberen deskribatzen duen lege fisikoa termodinamikaren bigarren legea da: denbora pasa ahala sistema isolatu baten entropia beti handitzen da. Lege hau fenomenologikoa da, eta haren oinarri mikroskopikoa aztertzean argi ikusten da ez dela fisikaren oinarrizko lege haustezin bat, baizik eta estatistikoki (oso probabilitate handiz) betetzen den lege bat. Interpretazio mikroskopiko honi jarraituz, entropiaren handitzearen zergatia bilatzea galdera hutsala litzateke. Sistemak egoera mikroskopiko askoz gehiago dauzka eskuragarri entropia altukoak entropia baxukoak baino. Egoera horiek guztiak probabilitate berdinaz gertatzen direla suposatuz, entropia handitzea guztiz naturala da; kontrakoa litzateke arraroa. Beraz, sistema baten eboluzioa behatzean galdetu beharrekoa ez da zergatik entropia handitzen den, baizik eta zergatik sistemaren hastapen-baldintzak entropia baxukoak ziren.

Perfumearen adibidera bueltatuz, galdera zuzena ez da zergatik perfume-molekulak gela osora hedatzen diren. Hori da probabilitate oso handiz gertatu behar dena; kontrakoa, gela osoan banaturik dagoen perfume bat espontaneoki botilaren barnean kontzentratzen ikustea, izango litzateke arraroa. Galdera egokia, beraz, honakoa izango litzateke: zergatik zegoen hasieran perfume guztia botilaren barnean? Kasu honetan, badakigu pertsona bat, perfumea destilatzeko makina batekin batera, dela arduraduna hori gerta dadin. Perfumea botilan sartzen, eta beraz sistema horren entropia baxuko egoera batean jartzen, energia erabili behar izan da eta derrigorrez ingurunearen entropia handitzea ekarri du.

Arrazonamendu hau unibertso osora estrapolatzeko, grabitatearen indarra ere kontuan hartu beharra dago, naturaren lau oinarrizko indarretatik hau baita distantzia handira nagusia dena. Beste hiruretatik indar ahulak eta bortitzak distantzia mikroskopikoetan soilik dute eragina eta, elektromagnetikoari dagokionez, unibertsoan dauden objektuek karga neutroa izan ohi dute. Horrez gain, grabitatearen izaera erakarlea dela eta, hainbat partikulaz osaturiko sistemaren entropia handitzearen ideia intuitiboa alda daiteke. Euren arteko eragin grabitatorioa baztergarria bada, partikulek eskuragarri duten espazio osoa betetzeko joera dute. Haatik, euren arteko eragin grabitatorioa ez bada baztergarria, sistemaren joera partikulen arteko distantzia minimizatzekoa izango da. Baldintza oso orokorren pean, sistemaren masa osoa eta partikulen artean existitu daitezkeen beste interakzioak gorabehera, sistema horren amaierako egoera zulo beltz bat izango litzateke: 
partikula guztiak puntu batean kontzentratzea, singularite grabitatorio bat eratuz. Hauek dira, izatez, entropia maximoko egoerak.

Erlatibitate orokorra da gaur egunean daukagun teoriarik onartuena grabitatearen efektuak deskribatzeko. Testuinguru honetan ez da existitzen entropiaren definizio orokorrik [16]. Alde batetik, mekanika estatistikoaren emaitzak lortzeko, ergodizitatea (mikroegoera guztiak gertatzeko probabilitatea bera dela) eta mekanikaren denboraren translazioekiko inbariantzia erabili ohi dira. Kontzeptu hauek ez dute zentzurik erlatibitate orokorraren hainbat soluziotan; adibidez, etengabe hedatzen ari den unibertso batean. Bestalde, grabitate kuantikoaren teoria osorik ez da ezaguna gaur egun. Horrelako teoria batek grabitatearen askatasun-gradu mikroskopikoei buruzko informazioa emango liguke. Ondorioz, sistema grabitatorioen entropiaren kontzeptua ez dago argi eta oso zaila da unibertsoaren entropiaren definizio zehatz bat ematea.

Hala ere, zulo beltzak honen salbuespen nabarmena dira. Bekenstein eta Hawking-en lanen ondoren [17, 18], ezaguna da zulo beltz baten entropia bere horizontearen $A$ azalerarekin erlazionaturik dagoela honako moduan:

$$
S_{B H}=\frac{k_{B}}{4 l_{P}^{2}} A,
$$

non $l_{P}=1.6 \times 10^{-35} \mathrm{~m}$ Planck-en luzera den. Esan bezala, hauek dira entropia altueneko sistemak. Adibidez, eguzkiaren entropia bere oraingo egoeran $10^{58} k_{B}$ ingurukoa da. Baina bere masa osoa zulo beltz batean kontzentraturik balego, bere entropia $10^{77} k_{B}$ ingurukoa izango litzateke, hau da, $10^{19}$ aldiz handiagoa!

Kosmologiaren modelo estandarraren arabera, gure unibertsoa eztanda handian (ingelesez big-bang ) izeneko singularitate batean hasi zen. Bertan espazioa eta denbora sortu ziren, unibertsoan beha daiteken energia eta materia osoarekin batera. Eztanda handiaren ondoren, materiaren egoera oinarrizko partikulen plasma oso homogeneo eta uniforme bat zen. Grabitatea albo batera utziz, honelako egoera bat oso entropia altukoa dela ondorioztatuko genuke. Baina grabitatearen askatasun graduak ere kontuan izan behar dira eta, ikusi dugun moduan, oso kontzentraturik dagoen materia uniformeki banaturik dagoena baino entropia altuagokoa izan daiteke grabitatearen eraginez.

Hasieran unibertsoa opakua zen argiarentzat. Partikulen kontzentrazioa oso altua zenez fotoi baten ibilbide askea oso laburra zen; ia berehala xurgatzen baitzuen beste partikularen batek. Eztanda handia gertatu eta 380.000 urte geroago, unibertsoa gardena bihurtu zen. Orduan emititu ziren fotoiak guregana heldu daitezkeen lehenak dira. Fotoi horiek hondoko mikrouhineko erradiazioa (ingelesez cosmic microwave background) de- 
ritzona osatzen dute eta bere tenperatura $2.7 \mathrm{~K}$-ekoa da. Erradiazio horren entropia partikula bakoitzeko $10^{9} k_{B}$-koa da. Unibertso ikusgaian $10^{80}$ partikula daudela estimatzen da; beraz, hasierako unibertsoaren entropia $10^{89} k_{B}$ ingurukoa izan zen.

Entropiaren balio hori oso baxua dela ikusteko, gaur egungo unibertsoaren entropia estima dezakegu suposatuz gure galaxia unibertsoan dauden galaxia tipikoetako bat dela. Esne-bidearen entropia estimatzeko nahikoa da erdian kokaturik dagoen $10^{6} M_{\odot}$ masako zulo beltzaren entropia kalkulatzea. Masa horretako zulo beltz batentzat, BekensteinHawking formula erabiliz, partikula bakoitzeko $10^{21} k_{B}$ balioko entropia lortzen da.

Azkenik, unibertsoaren entropia maximoko egoera materia eta energia guztia zulo beltz bakar batean bildurik balego lortuko litzateke. Entropia maximo horren balioa $10^{123} k_{B}$ ingurukoa izango litzateke, edo $10^{43} k_{B}$ partikula bakoitzeko.

Laburtuz, hasierako unibertsoaren entropia gaur egungo unibertsoarenarena baino $10^{-12}$ aldiz txikiagoa izan zen eta unibertsoaren entropia maximoko egoera baino $10^{-34}$ aldiz txikiagoa! Zenbaki izugarri txiki hauek unibertsoaren hasierako egoeraren berezitasunaren berri ematen digute. Boltzmann-en formularen arabera, entropiaren esponentzialak entropia jakin bat duten mikroegoeren kopurua ematen digu. Hura erabiliz, kalkulatu egin daiteke zenbat mikroegoera dagozkion unibertsoaren egoera desberdin bakoitzari. Horrela, erraz ikus daiteke, hasierako unibertsoaren egoerari dagokion fase-espazioko mikroegoera bakoitzeko, entropia maximoko egoerari dagozkion $10^{10^{23}}$ egoera daudela! Fase-espazioan egoera bat ausaz aukeratuz gero, horixe izango litzateke daukagun probabilitatea gure unibertsoaren hasierako egoera bat aukeratzeko! [19]

Modu honetan, ikusi dugu eztanda handiaren ondorengo unibertsoaren egoera oso berezia eta entropia izugarri baxukoa izan zela. Baina, esan bezala, interpretazio honek hurrengo galdera uzten du irekita: zergatik izan zen hain berezia gure unibertsoaren hasiera? Honi erantzuteko, gaur egun argi ez dagoen arren, bi proposamen daude.

Alde batetik, printzipio antropikoa aipa dezakegu. Haren arabera behatzen dugun unibertsoa horrelakoa da gu existitzen garelako. Hau da, baldintza aproposak dituen unibertso batean soilik gara daiteke bizitza eta, beraz, nahiz eta mota askotako unibertsoak existitu izan diren edo existitu daitezkeen, gu horrelako unibertso berezi batean soilik bizi ahal izango ginateke. Beste alde batetik, eztanda handiaren inguruko prozesu fisikoak azaldu eta ulertzeko, beharrezkoa da grabitazio kuantikoaren teoria. Eta gerta liteke teoria horren efektu bat hauxe bera izatea: eztanda handiaren ondorengo unibertsoa oso entropia baxukoa izatea. 


\section{ONDORIOAK}

Artikulu honetan denboraren geziaren kontzeptua definitu eta aztertu dugu. Fisikaren lege eta prozesu desberdinek definitzen dituzten denboraren geziak ikusi ditugu; besteak beste, kuantikoa, erradiazioarena eta termodinamikoa. Azkenengo horrek, termodinamikaren bigarren legearen bidez, definitzen du denboraren gezi funtsezkoena.

Oinarrizko partikulek jarraitzen dituzten legeak guztiz simetrikoak dira denboran. Baina partikula askoz osaturiko sistemek termodinamikaren lege itzulezinak betetzen dituzte. Asimetria honek itzulezintasunaren paradoxa planteatzen du: nola izan liteke lege itzulgarrietatik denboran asimetria bat ondorioztatzea? Hainbat zientzialariren aburuz, kaos dinamikoa dugu paradoxa honen ebazpena. Nahiz eta printzipioz posiblea izan sistemaren eboluzio zehatza lortzea, eboluzio hori zehazki aurresateko gaitasuna galtzen dugu hastapen-baldintzak neurtzean saihestezinak diren errore esperimentalak eta sistemaren gainean nahi eta nahi ez eragiten egongo diren kanpo interakzioak direla eta.

Beste ikerlarien arabera, entropiaren handipena ez da zertan azaldu behar, mekanika estatistikoaren intepretrazioari jarraituz, naturalena entropia handitzea baita, sistemak entropia altuko entropia baxuko baino mikroegoera gehiago baitauzka eskuragarri. Ikuspuntu honen arabera, azaldu beharrekoa gure unibertsoaren hasierako entropia baxuko egoera litzateke. Izatez, ikusi dugun moduan, gure unibertsoaren hasiera izugarri berezia izan zen. Unibertsoaren fase-espazioko egoera bat ausaz hartuz gero, $10^{-10^{23}}$ izango litzateke horrelako egoera bat aukeratzeko probabilitatea. Hau da, guztiz baztergarria. Horren azalpena zein izan litekeen ez dago argi, baina bi ildotatik joan daiteke. Alde batetik, printzipio antropikoa: unibertsoa horrelakoa da gu existitzen garelako. Bizitza sortzeko baldintzarik eskaintzen ez duen unibertso bat behatzea ezinezkoa izango litzateke beraz. Bestetik, oraindik ezezaguna den grabitazio kuantikoaren teoria oso bat beharrezkoa da unibertsoaren sorrera guztiz ulertzeko, eta teoria hori izan daiteke galdera honen erantzunaren giltza.

\section{ERREFERENTZIAK}

[1] SAN AGUSTIN HIPONAKOA, Confessiones (400).

[2] A.S. EDDINGTON. 1929. The nature of the physical world, Cambridge University Press.

[3] L. CARROLL. 1865. Alice's adventures in Wonderland.

[4] I. PRIGOGINE eta I. STENGERS. 1984. Order out of chaos, Bantam.

[5] P.S. LAPLACE. 1814. Essai philosophique sur les probabilités. 
[6] H. REICHENBACH. 1956. The direction of time, University of California Press.

[7] I. NEWTON. 1687. Philosophiae Naturalis Principia Mathematica.

[8] C. SÁNCHEZ DEL RÍO. 1997. Física cuántica, Ediciones Pirámide.

[9] J.H. CHRISTENSON, J.W. CRONIN, V.L. FITCH eta R. TURLAY. 1964. «Evidence for the $2 \pi$ decay of the $K_{2}^{0}$ meson», Phys. Rev. Lett. 13, 138.

[10] J.A. WHEELER eta R.P. FEYNMAN. 1945. «Interaction with the Absorber as the Mechanism of Radiation», Rev. Mod.Phys. 17, 157.

[11] R. CLAUSIUS. 1875. The Mechanical Theory of Heat.

[12] L. BOLTZMANN. 1872. Weitere Studien über das Wärmegleichgewicht unter Gasmolekülen, Sitzungsber. Kais. Akad. Wiss. Wien Math. Naturwiss. Classe 66, 275.

[13] J. LOSCHMIDT. 1876. Uber den Zustand des Wärmegleichgewichtes eines Systems von Körpern mit Rücksicht auf die Schwerkraft. 1. Teil, Sitzungsber. Kais. Akad. Wiss. Wien Math. Naturwiss. Classe 73, 128.

[14] P. COVENEY eta R. HIGHFIELD. 1991. The arrow of time: a voyage through science to solve time's greatest mystery, Fawcett.

[15] H. PRICE. 1996. Time's arrow and Archimedes' point, Oxford University Press.

[16] R. WALD. 2006. «The arrow of time and the initial conditions of the universe», Studies in History and Philosophy of Science Part B 37, 394.

[17] J.D. BEKENSTEIN. 1973. «Black holes and entropy», Phys. Rev. D 7, 2333.

[18] S.W. HAWKING, «Black hole explosions», Nature 248, 5443 (1974); «Particle creation by black holes», Comm. Math. Phys. 43, 199 (1975).

[19] R. PENROSE. 2007. The road to reality: a complete guide to the laws of the universe, Vintage. 